\title{
Advancing the science and management of flats fisheries for bonefish, tarpon, and permit
}

\author{
Aaron J. Adams • Steven J. Cooke
}

Received: 28 July 2015 / Accepted: 27 August 2015 / Published online: 12 September 2015

(C) Springer Science+Business Media Dordrecht 2015

\begin{abstract}
The fish of the sub-tropical and tropical flats including bonefish (Albula spp.), Atlantic tarpon (Megalops atlanticus), and permit (Trachinotus falcatus), capture the imagination of specialized coastal marine recreational anglers. Until recently, little was known about the biology and natural history of these iconic species. Flats ecosystems are under threat from coastal development and environmental change while basic information on demographics and population size is lacking. This makes it difficult to understand the consequences of these threats, or to formulate potential management strategies. Through extensive partnerships involving anglers, industry, conservation organizations, natural resource agencies, and academics, the mysteries surrounding these species are starting to be solved. Nonetheless, many challenges remain. The systematics of these fish is complex, particularly for the bonefish which include a number of cryptic species. Identifying the timing and habitats associated with reproduction remain high priority such that management efforts can target protecting that important life-history event. Information on the spatial ecology of flats fish at various spatial scales is being elucidated by electronic tagging
\end{abstract}

\footnotetext{
A. J. Adams $(\bowtie)$

Bonefish \& Tarpon Trust and Department of Biological Sciences, Florida Institute of Technology, Vero Beach Marine Laboratory, 805 46th Place East, Vero Beach, FL 32963, USA

e-mail: aaronadams@fit.edu

S. J. Cooke

Department of Biology, Carleton University, 1125 Colonel By Dr, Ottawa, ON K1S 5B6, Canada
}

studies and angler tagging programs. Habitat science for these fish continues to improve but there is still need to identify effective habitat restoration strategies. Catch-and-release science has improved dramatically (especially for A. vulpes in The Bahamas) although there is need to for additional work across regions and species. Targeted species-specific management strategies (e.g., catch-and-release regulations) as well as more ecosystem-level strategies (e.g., habitat protection and fishing effort management) are increasingly being used for active management of flats fish and their habitats. Partnerships will remain key to addressing outstanding research questions and in working cooperatively to ensure that evidence (both scientific and stakeholder knowledge) forms the basis for management decisions.

Keywords Recreational fishing - Conservation · Fish habitat . Catch and release . Citizen science

\section{Context}

Coastal marine waters in tropical and sub-tropical regions are often characterized by expansive shallow areas with adjacent tidal creeks collectively referred to as "flats". The flats are a complex habitat mosaic comprised of mangroves, sea grass, benthic algae, sand, coral rubble, limestone, and mud bottom that supports an inherently diverse community that includes resident species and species that use these habitats as nurseries (Barbier 
et al. 2011). Bonefish (Albula spp.), Atlantic tarpon (Megalops atlanticus), and permit (Trachinotus falcatus) represent some of the more prominent fish fauna on the flats, not only because of their relatively large size, but also because they generate many ecosystem services, particularly related to provisioning and culture. In many locations, they support highly valuable recreational fisheries (known as 'flats fisheries'), such as in the Florida Keys (USA) where the annual economic of impact of the flats fishery exceeds $\$ 465$ million (Fedler 2013). Despite the economic and ecological importance of these species, until recently little was known about their biology, and large gaps remain.

In response to a perceived decline in bonefish and tarpon abundance in the recreational flats fishery, in 1998, the non-profit conservation group Bonefish \& Tarpon Unlimited was formed by anglers, fishing guides, and members of the recreational fishing industry. The organization changed its name to Bonefish \& Tarpon Trust in 2009 (see http://btt.org). In 1998, there were fewer than 15 published studies on the biology of bonefish, tarpon or permit, so a focus of the organization was to fund research that contributed to a greater knowledge of these species and was relevant to conservation.

The first International Bonefish \& Tarpon Symposium was held in 2003, and was the first event to bring together scientists, anglers, and the recreational fishing sector with an interest in the conservation of these species and of the fishery. Subsequent symposia have been held in 2006, 2011, and 2014, with the next event schedule for 2017. The symposium series has been a success in raising awareness of and interest in science and conservation of bonefish, tarpon, and permit, and in increasing interactions between the scientific and angling communities. The proceedings from the 2006 symposium were published as a book (Ault 2008) and study results of some of the other symposia presentations have been published in peer reviewed journals, but never as a cohesive and coordinated special issue. A series of papers from the most recent (i.e., November 7-8, 2014) symposium are published in the journal Environmental Biology of Fishes. Here we summarize some of the more salient and meaningful scientific and management outcomes that have emerged from the growing literature base including those papers published as part of the special issue.

\section{Systematics and natural history}

Members of the Albula genus (family Albulidae) are found throughout the world's shallow tropical seas. Because Albula morphology has been conserved across species, taxonomic identification remains difficult so the Albula genus is currently in a state of revision. However, recent work by Wallace (2015) and others (Colborn et al. 2001; Hidaka et al. 2008; Wallace and Tringali 2010; Kwun and Kim 2011; Pfeiler et al. 2011) has made significant inroads into the taxonomic status of this complex genus.

In the Caribbean and western North Atlantic, there are two described species - A. vulpes and A. nemoptera - but two additional cryptic species are likely (Colborn et al., 2001; Adams et al. 2008; Bowen et al. 2008; Wallace and Tringali 2010). In the Indo-West Pacific, A. glossodonta is broadly distributed, and in Hawaii, Fiji and northern Australia, it is sympatric with $A$. argentea (Albulidae) (also referenced as A. neoguinaca and A. forsteri). A. oligolepis is recorded from the Indian Ocean (Hidaka et al. 2008), A. virgata from Hawaii (Jordan and Jordan 1922) and A. koreana has been recently described for Korea and Taiwan (Kwun and Kim 2011), but little is known about these species.

Spawning in Albula spp. is poorly known except for A. vulpes, but it is likely that other Albula spp. show similar patterns and behaviours. From October through April or May, schools of adult A. vulpes migrate from nearshore and inshore habitats to form large prespawning aggregations before moving offshore for spawning in deep waters $(>300 \mathrm{~m})$ on the full moon (Danylchuk et al. 2011). Planktonic duration of A. vulpes and A. glossodonta leptocephali is 41-71 days, with recruitment to inshore nurseries from summer through winter, reflecting either a prolonged spawning season (Mojica et al. 1994; Friedlander et al. 2008) or similar seasonal spawning by co-occurring cryptic species. Juvenile and adult stage Albula spp. use a range of shallow, nearshore habitats that make up the flats habitat mosaic (Shaklee and Tamaru 1981; Colton and Alevizon 1983; Kaufmann 2001; Layman and Silliman 2002; Layman et al. 2004; Nero and Sullivan-Sealey 2005; Adams et al. 2008; Friedlander et al. 2008).

Bonefishes feed predominately on benthic invertebrates (bivalves, polychaetes, crustaceans) but also on small fishes; piscivory increases with size (Warmke and Erdman 1963; Friedlander et al. 1997; Crabtree et al. 1998; Snodgrass et al. 2010). 
Recent aging of large bonefish has revealed that A. vulpes live to at least 20 years in the Florida Keys (Larkin 2011) and 25 years in the Bahamas (C. Haak, pers. Comm.), reaching sizes $>70 \mathrm{~cm}$ (Crabtree et al. 1996). Pacific A. glossodonta can reach $8 \mathrm{~kg}$ in mass and $90 \mathrm{~cm}$ in length (Myers 1991). On average, A. vulpes and $A$. glossodonta mature between 3.5 and 4.5 years between 42 and $49 \mathrm{~cm}$, with males maturing at smaller sizes and younger ages than females (Crabtree et al. 1997; Friedlander et al. 2008). Size and age at maturity and dimorphic growth patterns are unknown for most other bonefishes and may differ among regions. For example, growth rates of $A$. vulpes in the Bahamas, Central America and insular Caribbean (Adams et al. 2008; C. Haak, UMass, unpublished data) may be three times slower than growth rates in the Florida Keys (Crabtree et al. 1996), and growth may vary even at the scale of the Bahamas archipelago (C. Haak, pers. Comm.).

A caveat to our understanding of Albula spp. is the difficulty in assigning observations to a species. Because of the considerable geographic overlap of species and the conservative morphometrics of the genus (Adams et al. 2013; Wallace 2015), it is important that new research identify the species being studied, and that previous studies be examined or repeated to ensure that observations were applied to the appropriate species. This will ensure that the correct information is applied to conservation. For example, the recreational fishery in the Caribbean depends upon A. vulpes ( $>95 \%$ of bonefish caught by recreational anglers were genetically identified as $A$. vulpes), but $>95 \%$ of juvenile bonefish caught during sampling along sandy beaches were A. goriensis (Adams et al. 2008). Ongoing research has identified juvenile $A$. vulpes habitats as open sandy-mud bottoms in bays (C. Haak, University of Massachusetts, pers. Com.). Without genetic identification of the species, improper nursery habitat conservation measures would have been pursued. Similarly, proper management of the bonefish fishery in Hawaii, which has both catch and release and harvest components, would be difficult at best without a full understanding of how $A$. glossodonta and $A$. virgata partition niche space (Donovan et al. 2015).

In contrast to bonefishes, the taxonomy of Atlantic tarpon (family Megalopidae) and permit (family Carangidae) are clear. Atlantic tarpon are widely distributed in the North Atlantic Ocean, Gulf of Mexico and Caribbean Sea. Latitudinal range is limited by sensitivity to low water temperature (Zale and Merrifield 1989); in the extremes of their range, tarpon experience winter thermal mortality circa $10^{\circ} \mathrm{C}$ (Robins et al. 1977) and have an upper lethal thermal limit of $40{ }^{\circ} \mathrm{C}$ (Moffett and Randall 1957). Adults have been observed as far north as Nova Scotia and Ireland (Twomey and Byrne 1985), but these likely represent vagrants.

Although spawning has not been observed and specific locations have not yet been identified, it is presumed to occur offshore based on collection of day old larvae (Crabtree et al. 1992; J. Shenker, Florida Institute of Technology, unpubl. Data) and by following offshore movements of adult fish (Ault et al. 2008). Schools of gravid individuals migrate from nearshore and inshore habitats to form large pre-spawning aggregations approximately $2-5 \mathrm{~km}$ offshore before moving presumably up to 200-250 km offshore where 3- to 6-day old larvae were collected (Crabtree et al. 1992). These spawning events relate to summer lunar phases in Florida (Crabtree 1995; Shenker et al. 2002), and spawning seasons are more protracted in tropical waters such as Costa Rica (Crabtree et al. 1997) and Puerto Rico (Zerbi et al. 2001).

The planktonic leptocephalus stage is 20-40 days (Shenker et al. 2002). Post-metamorphic juveniles are euryhaline and have been collected in waters ranging from 0 to 45 PSU. The vascularized swim bladders of tarpon allow aerial respiration, permitting juveniles to inhabit hypoxic inshore waters where they presumably experience low predation rates and have little competition for prey (Schlaifer and Breder 1940; Geiger et al. 2000). Juvenile habitats include stagnant pools, back waters, ephemeral coastal ponds and hurricane and storm overwashes, swales, and mangrove swamps and marshes, as well as manmade habitats such as mosquito impoundments and artificial wetlands (Wade 1962; Dahl, 1965; Zerbi et al. 2001; Jud et al. 2011). As they grow, juveniles spend significant time in larger rivers, bays and estuaries before exhibiting the more extensive movements of adults (Crabtree et al. 1995). Adults [>120 cm fork length (FL)] also inhabit inshore waters and bays, across a wide range of salinities (fresh to hypersaline) and temperatures $\left(17-40{ }^{\circ} \mathrm{C}\right.$ ) (Zale and Merrifield 1989; Crabtree et al. 1995), and are capable of seasonal migrations along the southeast coastline of the United States and the Gulf of Mexico (Ault et al. 2008).

Juveniles prey upon zooplankton, small crustaceans, polychaetes and insects that frequent inshore nurseries 
(Harrington 1958; Jud et al. 2011). As older juveniles and adults begin to inhabit deeper-water habitats such as lagoons, creeks, canals and sloughs for emigration to coastal bays, their diet transitions to larger crustaceans (penaeid shrimps, swimming crabs), polychaetes, and a suite of fishes (Whitehead and Vergara 1978; Boujard et al. 1997).

Atlantic tarpon reach maximum ages of 43-78 years (Crabtree et al. 1995; Andrews et al. 2001) and may exceed $2 \mathrm{~m}$ in length and $110-130 \mathrm{~kg}$ in mass (Crabtree et al. 1997; J.S. Ault University of Miami, pers. Comm.). Although there is considerable variation across its range, Atlantic tarpon reach sexual maturity at $>130 \mathrm{~cm}$ and 7-12 years (de Menezes and Paiva 1966; Chacon-Chaverri 1993; Crabtree et al. 1997).

Permit inhabit coastal areas of the North Atlantic as far north as Massachusetts and throughout the Gulf of Mexico (GOM), but are common year-round in coastal waters of the Caribbean, and seasonally in subtropical and warmtemperate regions. Permit spawn at reef promontories and offshore structures (e.g., artificial reefs) (Graham and Castellanos 2005, Crabtree et al. 2002). Spawning occurs during summer months in Florida (Crabtree et al. 2002), but for longer durations at lower latitudes (Graham and Castellanos 2005). There is disagreement on the planktonic larval duration (PLD) of permit: Adams et al. (2006) determined the PLD was 15-18 days, but Bryan et al. (2015) used a time period of 20 to 30 days for models of planktonic larval transport. This suggests that more work is needed on larval dynamics of this species.

Settlement and early juvenile habitat is windward sandy beaches (Adams et al. 2006). Juvenile permit undergo ontogenetic shifts in diet (Carr and Adams 1973). The diet of juveniles $15-20 \mathrm{~mm} \mathrm{SL}$ is dominated by small fish and mysids. Permit $61-70 \mathrm{~mm}$ eat mostly crabs and gastropods (Carr and Adams 1973). Larger crustaceans and mollusks dominate the diet of 50$100 \mathrm{~mm}$ permit, and mollusks are the predominant food of permit 100-138 mm (Finucane 1969).

Movement and migration patterns of permit remain unknown. Determining these patterns has been difficult, as summarized by Ahrens et al. (2015). Difficulties include: overall low catch rates (one of the reasons permit are so appealing to flats anglers is the difficulty in catching them); low recapture reporting rates; low retention of dart tags. In addition, small satellite tags have been experimentally deployed on adult permit without success (Adams, unpubl. Data). In tank studies, permit $>7 \mathrm{~kg}$ were fitted with a small satellite tag, and showed no deleterious effects. However, three field trials failed: in two trials, the tags popped to the surface $>2$ weeks early, and had teeth marks on them, indicating either predation or fish (e.g., barracuda) mistaking the tag for prey; in the third trial the tag never reported.

\section{New research addresses important issues}

Flats fish on the move

Recent and ongoing research using mark-recapture to track bonefish movements shows high fidelity to small home ranges $(>75 \%$ of bonefish are recaptured within $1 \mathrm{~km}$ of the tagging location) (Adams unpubl. Data), but Murchie et al. (2013) used acoustic telemetry to identify larger home ranges. Recent acoustic tracking of bonefish identified pre-spawning and spawning sites at locations far removed from home range foraging areas, and documented movements offshore to spawn (Danylchuk et al. 2011). Ongoing research is further examining spawning migrations and identifying spawning sites. For example, acoustic telemetry is being used to track adult bonefish from foraging grounds to pre-spawning locations on Grand Bahama Island (Murchie et al. 2015) and on Abaco (Adams unpubl. Data) in the Bahamas, and suggests that the bonefish population for an island may rely on one or a few spawning sites. Identification of spawning migration pathways and pre-spawning sites is necessary for prioritizing locations for habitat protections and harvest regulations.

For tarpon and other species that may make longer seasonal migrations and that undergo more dramatic ontogenetic shifts than bonefish, other methods for tracking movements are needed. For example, Ault (2008) has used satellite tags to track seasonal migrations of adult tarpon, an approach that has also revealed information on smaller scale movements and environmental variables (Luo and Ault 2012). Seeley et al. (2015) tested the applicability of using elemental analysis of tarpon scales to track their movements based on salinity - an important focus given the reliance of tarpon on coastal and wetland habitats during their early life history.

There have also been important innovations in the study of the spatial ecology of larval life-stages. Bryan et al. (2015) used sophisticated oceanographic modeling to characterize the transport patterns of larval permit in the Florida Keys. The authors noted important cross- 
jurisdictional transport processes, which emphasizes the need for approaching management of flats fish on a regional basis.

\section{Habitat science and management}

As is the case for many coastal fish species (Turner et al. 1999; Jones et al. 2004; Halpern et al. 2007), overharvest and habitat loss or degradation are the top anthropogenic threats to bonefish, tarpon, and permit. In fact, a recent IUCN Red List assessment classified tarpon as Vulnerable, and bonefish species Albula vulpes as Near Threatened, and A. glossodonta at Vulnerable (Adams et al. 2013), all based on a combination of harvest, habitat loss, and anticipated continuation of habitat loss and degradation. Given that these species inhabit shallow tropical ecosystems that are especially vulnerable to changes in sea level and water temperature, there is also concern about the impacts of climate change.

The wide range of coastal habitats these species require creates challenges for conservation. Available data indicate that all species are offshore spawners, and all undergo ontogenetic, seasonal and spawning movements: juveniles are obligate inhabitants of shallow coastal or estuarine nursery habitats; adults use an expanded and diverse range of coastal habitats; spawning occurs in offshore waters distinct from normal foraging grounds. Given projections that by the year $2025,75 \%$ of the world's population may reside in coastal areas (Hinrichsen 1998), the coastal ecosystems that support bonefish, tarpon, and permit will likely face increasing habitat loss, habitat degradation, and overfishing (Hughes 1994; Lapointe et al. 1994). In Belize, Steinberg (2015) documents a troubling mix of these threats to the flats fishery in Belize.

\section{Catch-and-release science}

Due to angler ethics toward these species, and to their high economic impact, the recreational fisheries for bonefish, tarpon, and permit are primarily catch and release in many locations: in Florida, bonefish and tarpon are catch and release only; in Belize and Puerto Rico, bonefish, tarpon, and permit are catch and release only; in the Bahamas there is no commercial sale of bonefish; in marine protected areas where the flats fishery occurs in Cuba, bonefish, tarpon, and permit are catch and release only. However, despite the common use of catch and release as a conservation tool, research on the effects of catch and release on bonefish and tarpon was undertaken only recently (e.g., Cooke and Philipp 2004; Danylchuk et al. 2007; Guindon 2011), and no such research has occurred on permit.

Prior research on catch and release effects on bonefish identified best handling practices to increase postrelease survival of bonefish (e.g., Danylchuk et al. 2007), and this information has been used to formulate education programs for recreational anglers. However, Hannan et al. (2015) find unexpected impacts from sunscreen - a common product used by flats fishers to prevent skin damage from sun exposure. This will require further modification of education materials.

Prior to the study by Brownscombe et al. (2015) all of the previous research of catch and release effects on bonefish had been conducted in the Bahamas. Similar to previous studies, Brownscombe et al. (2015) found that fight time, air exposure, and handling time were important factors influencing the likelihood of bonefish survival after release. However, they also found that physiological stress was greater in association with warmer water temperatures found at the lower latitude of their study site in Puerto Rico, which may have implications for other Caribbean fisheries. Given that water temperature has strong influence on bonefish physiology (Nowell et al. 2015) under normal (no fishing) conditions, the effects of water temperature on postrelease survival (and thus the viability of catch and release as a conservation tool) need to be considered in conservation plans.

\section{Managing and conserving flats fisheries}

There is growing interest in engaging the recreational fishing community in conservation (e.g., Danylchuk and Cooke 2011). Although the flats fishery occurs over a wide geographic range (e.g., Caribbean Sea), the individual fisheries are geographically small, either the size of a nation (e.g., Belize) or an island (e.g., Abaco, Bahamas). In addition, the threats to these catch and release fisheries tend to be external to the fisheries (i.e., habitat loss due to development, commercial harvest). These characteristics make angler buy-in to conservation more likely (Cowx et al. 2010). Given the broad use of the flats habitat mosaic through their ontogeny and the charisma from their economic and cultural 
importance, these fisheries have been proposed as tools for habitat conservation (Adams and Murchie 2015), and angler participation will be an essential component to this effort. An important component of angler buy-in to conservation is their participation in data acquisition, especially for bonefish, tarpon, and permit for which data are scarce (Adams et al. 2013). For example, angler-generated data are essential for fisheries management in Hawaii (Kamikawa et al. 2015), and spatial data on fishing effort has been an essential part of the data gathering effort for a revised spatial management strategy in the Florida Keys National Marine Sanctuary (Black et al. 2015). Angler-scientist collaborations are not without difficulties, however, as was revealed in a recent study that expended considerable effort with limited results using angler-based mark-recapture to track movements of permit (Ahrens et al. 2015).

\section{The flats fisheries of the future - challenges and opportunities}

Much research has been conducted since the first symposium in 2003, due in large part to extensive partnerships within academia, between academia and NGOs and resource management agencies, as well as between scientists and recreational anglers. The latter is especially encouraging since a focus of the symposia has been to increase interactions between scientists and anglers. Continued partnerships will be necessary moving forward.

Partnerships will be especially important as research addresses the complex arrangement of species and geography. For example, the geographic distributions of Albula species in the Pacific and Indo-Pacific oceans means that species composition of fisheries and Albula species interactions differ among locations. In the Caribbean, A. vulpes supports the recreational fishery throughout the region, but interactions with predators, prey, and anthropogenic impacts differ among locations. Thus, although there has been considerable research on A. vulpes in recent years, most has occurred in the Bahamas, and has not been tested in other locations. Similarly, most research on tarpon and permit has occurred in the USA rather than in the Caribbean, which is the center of each species' geographic distribution.

The nature of the fisheries for bonefish, tarpon, and permit, and the socio-geography of their occurrence provide both opportunities and challenges for research and conservation. For example, data are generally lacking on fisheries for these species due to a lack of financial resources of the management agencies of the countries where the fisheries occur (Adams et al. 2013). This creates an opportunity to provide the expertise needed to conduct the necessary research, but also the challenge of funding the research. Another challenge is the fact that catch and release fisheries do not capture data required for traditional stock assessments (Adams et al. 2013). This is an opportunity to use creative and innovative methods to acquire data appropriate for managing a catch and release fishery. This might include working with recreational fishers to acquire data (including in the form of stakeholder knowledge on historical trends; Frezza et al. 2015) to monitor trends in the fishery over time, such as catch per unit effort, fish size, fish spatial distribution, genetics (Guindon et al. 2015) and other data that can be used to derive indices to be applied to a management evaluation (Adams et al. 2013).

The expected continuation of environmental change due to habitat loss and degradation and climate change poses a particular challenge. Given the reliance of bonefish, tarpon, and permit on the flats habitat mosaic, for example, habitat fragmentation will have unknown consequences. Impacts might include changes to trophic structure, interruption of ontogenetic habitat shifts, a mismatch of physiological parameters and environmental variables, or a disconnect between spawning sites and juvenile habitats due to a shift in larval transport pathways resulting from changes in ocean currents resulting from climate change. Each of these scenarios requires attention so that management strategies can be revised for the future.

The economic value of the recreational fisheries for these species is appealing to resource managers. This is especially true in the developing world that comprises much of these species' geographic ranges. If managed properly, the catch and release flats fisheries can make significant contributions to local economies with relatively little infrastructure investment. However, these fisheries can still suffer from overcapitalization and overfishing: too much fishing effort can result in a decline in catch rates because fish may become 'educated' to anglers, thus reducing catchability and causing a decline in the quality of the fishery; improper catch and release practices may result in post-release mortality that is unsustainable. Thus, the economic value of the fisheries provide a great opportunity, but also the challenge to 
obtain the scientific information (e.g., fishing capacity) required to implement an effective conservation plan.

Finally, the economic value of these species might be used as a tool to increase interest in habitat conservation, thus addressing the top threats to the fisheries that these species support (Adams and Murchie 2015). For example, the $\$ 141$ million annual economic impact of the bonefish fishery in the Bahamas is reliant on the habitats that support bonefish life history. As research identifies the important habitat types (e.g., habitat characteristics of juvenile bonefish habitats) and habitats (the locations of the habitat types used by bonefish), spatial conservation plans can be proposed, with economic justification for their implementation. This provides an incentive to conduct this research in a timely manner, and a tool for applying research findings to conservation.

Acknowledgments The 2014 Bonefish \& Tarpon Symposium was made possible by sponsors, the contributions of many volunteers, and the participation of scientists, guides, anglers, and resource managers. Thank you to the symposium committee Jeff Storm Harkavy, mike Duckworth, Bill Stroh, Luis Menocal, Alex Lovett-Woodsum, Bill Klyn, Andy Mill, Steve Stanley. Thank you to sponsors Costa del Mar. Sunglasses, Carrabas Italian Grill, Hell's Bay Boatworks, Bass Pro Shops, International Game Fish Association, Belcampo Belize, Nautilus Reels, Orvis, Coldpruf, Deep Water Cay Club, Hardy, Enrico Puglisi, Bote Boards, Sweetwater Brewery, Tito's Vodka, Wildlife Foundation of Florida, Yellow Dog Flyfishing Adventures, South Holston River Lodge, Frontiers Travel, Fay Ranches. We are indebted to the many reviewers who contributed constructive reviews of the manuscripts.

\section{References}

Adams AJ, Dahlgren C, Kellison GT, Kendall MS, Layman CA, Ley JA, Nagelkerken I, Serafy JE (2006) Nursery function of tropical backreef systems. Mar Ecol Prog Ser 318:287-301

Adams AJ, Wolfe RK, Tringali MD, Wallace E, Kellison GT (2008) Rethinking the status of Albula spp. biology in the Caribbean and western Atlantic. In: Ault JS (ed) Biology and management of the world's tarpon and bonefish fisheries. CRC Press. Boca Raton, FL

Adams AJ, Horodysky AZ, McBride RS, MacDonald TC, Shenker J, Guindon K, Harwell HD, Ward R, Carpenter K (2013) Conservation status and research needs for tarpons (megalopidae), ladyfishes (elopidae), and bonefishes (albulidae). Fish Fish 15(2):280-311

Adams AJ, Murchie KJ (2015) Recreational fisheries as conservation tools for mangrove habitats. Pages 43-56 in KJ Murchie and PP Daneshgar, editors. Mangroves as fish habitat. American Fisheries Society, Symposium 83. Bethesda, Maryland.
Ahrens R, et al (2015) Evaluating the efficacy of the Florida Key's angler-assisted permit tagging program. Environ Biol Fish. doi:10.1007/s10641-015-0426-0

Andrews AH, Burton EJ, Coale KH, Cailliet GM, Crabtree RE (2001) Radiometric age validation of Atlantic tarpon, Megalops atlanticus. Fish Bull 99:389-398

Ault JS (ed) (2008) Biology and management of the world tarpon and bonefish fisheries. CRC Press. Boca Raton, FL.

Ault JS, Humston R, Larkin MF, Perusquia E, Farmer NA, Luo J, Zurcher N, Smith SG, Barbieri LR, Posada JM (2008) Population dynamics and resource ecology of Atlantic tarpon and bonefish. In: Ault JS (ed) Biology and management of the world's tarpon and bonefish fisheries. CRC Press. Boca Raton, FL

Barbier EB, Hacker SD, Kennedy C, Koch EW, Stier AC, Silliman BR (2011) The value of estuarine and coastal ecosystem services. Ecol Monogr 81(2):169-193

Black BD, Adams AJ, Bergh C (2015) Mapping of stakeholder activities and habitats to inform conservation planning for a national marine sanctuary. Environ Biol Fish. doi:10.1007/ s10641-015-0435-Z

Boujard T, Pascal M, Meunier FJ, Le Bail PY (1997) Poissons de guyane. Guide écologique de l'approuague et de la réserve des nouragues. Institut National de la Recherche Agronomique, Paris $219 \mathrm{p}$

Bowen BW, Karl SA, Pfeiler E (2008) Resolving evolutionary lineages and taxonomy of bonefishes (Albula spp.). In: Ault JS (ed) Biology and management of the world's tarpon and bonefish fisheries, CRC Press. Boca Raton, FL

Brownscombe J, Griffin L, Gagne T, Haak CR, Cooke SJ, Danylchuk AJ (2015) Physiological stress and reflex impairment of recreationally angled bonefish in Puerto Rico. Environ Biol Fish. doi:10.1007/s10641-015-0444-y

Bryan DR et al (2015) Transport and connectivity modeling of larval permit from an observed spawning aggregation in the Dry Tortugas, Florida. Environ Biol Fish. doi:10.1007/ s10641-015-0445-x

Carr WES, Adams CA (1973) Food habitat of juvenile marine fishes occupying seagrass beds in the estuarine zone near crystal river, Florida. Trans Am Fish Soc 102:511-540

Chacon-Chaverri D (1993) Aspectos biometricos de una poblacion de sabalo, Megalops atlanticus (Pisces: megalopidae). Rev Biol Trop 41:13-18

Colborn J, Crabtree RE, Shaklee JB, Pfeiler E, Bowen BW (2001) The evolutionary enigma of bonefishes (Albula spp.): cryptic species and ancient separations in a globally distributed shorefish. Evolution 55:807-820

Colton DE, Alevizon WS (1983) Feeding ecology of bonefish in Bahamian waters. Trans Am Fish Soc 112:178-184

Cooke SJ, Philipp DP (2004) Behavior and mortality of caughtand-released bonefish (Albula spp.) in Bahamian waters with implications for a sustainable recreational fishery. Biol Cons 118:599-607

Cowx IG, Arlinghaus R, Cooke SJ (2010) Harmonizing recreational fisheries and conservation objectives for aquatic biodiversity in inland waters. J Fish Biol 76:2194-2215

Crabtree RE (1995) Relationship between lunar phase and spawning activity of tarpon, Megalops atlanticus, with notes on the distribution of larvae. Bull Mar Sci 56:895-899 
Crabtree RE, Hood PB, Snodgrass D (2002) Age, growth, and reproduction of permit (Trachinotus falcatus) in Florida waters. Fish Bull 100:26-34

Crabtree RE, Cyr EC, Bishop RE, Falkenstein LM, Dean JM (1992) Age and growth of tarpon, Megalops atlanticus, larvae in the eastern gulf of Mexico, with notes on relative abundance and probable spawning areas. Environ Biol Fish 35:361-370

Crabtree RE, Cyr EC, Dean JM (1995) Age and growth of tarpon, Megalops atlanticus, from south Florida waters. Fish Bull 93: 619-628

Crabtree RE, Harnden CW, Snodgrass D, Stevens C (1996) Age, growth, and mortality of bonefish, Albula vulpes, from the waters of the Florida keys. Fish Bull 94:442-451

Crabtree RE, Chaverri DC, McLarney WO, Dean JM (1997) Reproduction of tarpon, Megalops atlanticus from Florida and costa Rican waters and notes on their age and growth. Bull Mar Sci 61:271-285

Crabtree RE, Stevens C, Snodgrass D, Stengard FJ (1998) Feeding habits of bonefish, Albula vulpes, from the waters of the Florida keys. Fish Bull 96:754-766

Dahl G (1965) La metamorfosis desde leptocephalus hasta estado postlarval en el sabalo Tarpon atlanticus (Cuv. et Val.). Autonoma Reginal de los Valles del Magdalena y Sinú 1-20.

Danylchuk AJ, Danylchuk SE, Cooke SJ, Goldberg TL, Koppelman J, Philipp DP (2007) Postrelease mortality of bonefish, Albula vulpes, exposed to different handling practices during catch-and-release angling in Eleuthera, the Bahamas. Fish Manag Ecol 14:149-154

Danylchuk AJ, Cooke SJ (2011) Engaging the recreational angling community to implement and manage aquatic protected areas. Cons Biol 25(3):458-464

Danylchuk AJ, Cooke SJ, Goldberg TL, Suski CD, Murchie KJ, Danylchuk SE, Shultz A, Haak CR, Brooks E, Oronti A, Koppelman JB, Philipp DP (2011) Aggregations and offshore movements as indicators of spawning activity of bonefish (Albula vulpes) in the Bahamas. Mar Bio 158:19811999

de Menezes MF, Paiva MP (1966) Notes on the biology of tarpon, Tarpon atlanticus (Cuvier and valenciennes), from coastal waters of ceara state. Brazil Arq Estac Biol Mar Univ Fed Ceara 6:83-98

Donovan MK et al (2015) Ecology and niche partitioning of two bonefish species in Hawai'i. Environ Biol Fish. doi:10.1007/ s10641-015-0427-z

Fedler A (2013) Economic impact of the Florida keys flats fishery. Report to Bonefish \& Tarpon Trust, FL 30p. http://www. bonefishtarpontrust.org/images/stories/BTT\%20-020Keys $\%$ 20Economic\%20Report.pdf. Accessed 8 Sept 2015

Finucane JH (1969) Ecology of the pomano (Trachinotus carolinus) and the permit (T. falcatus) in Florida. Trans Am Fish Soc 3:478-486

Friedlander AM, DeFelice RC, Parrish JD, Frederick JL (1997) Habitat resources and recreational fish populations at Hanalei bay, Kauai. Hawaii Cooperative Fishery Research Unit Report to Hawaii Department of Land and Natural Resources, HI 320 pp

Friedlander AM, Caselle JE, Beets J, Lowe CG, Bowen BW, Ogawa TK, Kelley KM, Clitri T, Lange M, Anderson BS (2008) Biology and ecology of the recreational bonefish fishery at Palmyra atoll national wildlife refuge with comparisons to other pacific islands. In: Ault JS (ed) Biology and management of the world's tarpon and bonefish fisheries. CRC Press. Boca Raton, FL

Frezza PE, Clem SE (2015) Using local fishers' knowledge to characterize historical trends in the Florida Bay bonefish population and fishery. Environ Biol Fish. doi:10.1007/ s10641-015-0442-0

Geiger SP, Torres JJ, Crabtree RE (2000) Air-breathing and gill ventilation frequencies in juvenile tarpon, Megalops atlanticus: responses to changes in dissolved oxygen, temperature, hydrogen sulfide, and $\mathrm{pH}$. Environ Biol Fish 59: 181-190

Graham RT, Castellanos DW (2005) Courtship and spawning behaviors of carangid species in Belize. Fish Bull 103:426432

Guindon KG (2011) Evaluating lethal and sub-lethal effects of catch-and-release angling in Florida's central gulf coast recreational Atlantic tarpon (Megalops atlanticus) fishery. Doctoral Dissertation, University of South Florida 163 pp

Guindon KG, et al (2015) An overview of the Tarpon Genetic Recapture Study in Florida - a citizen science success story. Environ Biol Fish. doi:10.1007/s10641-015-0440-2

Halpern BS, Selkoe KA, Micheli F, Kappel CV (2007) Evaluating and ranking the vulnerability of global marine ecosystems to anthropogenic threats. Cons Biol 21:1301-1315

Hannan KD, Zuckerman ZC, Haak C, Shultz AD (2015) Sun protection and catch-and-release angling: implications for fish health. Environ Biol Fish

Harrington RW Jr (1958) Morphometry and ecology of small tarpon, Megalops atlantica, valenciennes from transitional stage through onset of scale formation. Copeia 1 : 1-10

Hidaka K, Iwatsuki Y, Randall JE (2008) A review of the indopacific bonefishes of the Albula argentea complex, with a description of a new species. Ichth Res 55:53-64

Hinrichsen D (1998) Coastal waters of the world: trends, threats, and strategies. Island Press, Washington, DC 275 pp

Hughes TP (1994) Catastrophes, phase shifts, and large-scale degradation of a Caribbean coral reef. Science 265:15471551

Jones GP, McCormick MI, Srinivasan M, Eagle JV (2004) Coral decline threatens fish biodiversity in marine reserves. Proc Nat Acad Sci 101:8251-8253.

Jordan DS, Jordan EK (1922) A list of the fishes of Hawaii, with notes and descriptions of new species. Mem Carneg Mus 10: 6-7

Jud ZR, Layman CA, Shenker JM (2011) Diet of age-0 tarpon (Megalops atlanticus) in anthropogenically-modified and natural nursery habitats along the Indian river lagoon, Florida. Environ Biol Fish 90:223-233

Kamikawa KT, et al (2015) Bonefishes in Hawai'i and the importance of angler-based data to inform fisheries management. Environ Biol Fish. doi:10.1007/s10641-015-0421-5

Kaufmann R (2001) Bonefishing. Frank Amato Publications, Portland, OR $415 \mathrm{p}$

Kwun HJ, Kim JK (2011) A new species of bonefish, Albula koreana (albuliformes: albulidae) from Korea and Taiwan. Zootaxa 2903:57-63

Lapointe BE, Tomasko DA, Matzie WR (1994) Eutrophication and trophic state classification of seagrass communities in the Florida keys. Bull Mar Sci 54:696-717 
Larkin MF (2011) Assessment of south Florida's bonefish stock. Doctoral Dissertation, University of Miami 194 pages

Layman CA, Silliman BR (2002) Preliminary survey and diet analysis of juvenile fishes of an estuarine creek on Andros island, Bahamas. Bull Mar Sci 70:199-210

Layman CA, Arrington DA, Langerhans RB, Silliman BR (2004) Degree of fragmentation affects fish assemblage structure in Andros island (Bahamas) estuaries. Carib J Sci 40:232-244

Luo J, Ault JS (2012) Vertical movement rates and habitat use of Atlantic tarpon. Mar Ecol Prog Ser 467:167-180

Moffett AW, Randall JE (1957) The roger firestone tarpon investigation. University of Miami marine laboratory progress report 57-22. University of Miami, Miami, FL

Mojica R Jr, Shenker JM, Harnden CW, Wagner DE (1994) Recruitment of bonefish, Albula vulpes, around Lee stocking island, Bahamas. Fish Bull 93:666-674

Murchie KJ, Cooke SJ, Danylchuk AJ, Danylchuk SE, Goldberg TL, Suski CD, Philipp DP (2013) Movement patterns of bonefish (Albula vulpes) in tidal creeks and coastal waters of Eleuthera, the Bahamas. Fish Res 147:404-412

Murchie KJ, Shultz AD, Stein JA, Cooke SJ, Lewis J, Franklin J, Vincent G, Brooks EJ, Claussen JE, Philipp DP (2015) Defining adult bonefish (Albula vulpes) movement corridors around Grand Bahama in the Bahamian Archipelago. Environ Biol Fish. doi:10.1007/s10641-015-0422-4

Myers RF (1991) Micronesian reef fishes, Second edn. Coral Graphics, Barrigada, Guam 298 pp

Nero VL, Sullivan-Sealey K (2005) Characterization of tropical near shore fish communities by coastal habitat status on spatially complex island systems. Environ Bio Fish 73:437444

Nowell LB, Brownscombe JW, Gutosky LFG, Murchie KJ, Suski CD, Danylchuk AJ, Shultz A, Cooke SJ (2015) Swimming energetics and thermal ecology of adult bonefish (Albula vulpes): A combined laboratory and field study in Eleuthera, The Bahamas. Environ Biol Fish. doi:10.1007/ s10641-015-0420-6

Pfeiler E, Van der Heiden AM, Ruboyianes RS, Watts T (2011) Albula gilberti, a new species of bonefish (albuliformes: albulidae) from the eastern pacific, and a description of adults of the parapatric A. esuncula. Zootaxa 3088:1-14

Robins CR, Ray GC, Douglass J, Freund R (1977) A field guide to Atlantic coast fishes of north America. Houghton Mifflin Company, Boston 354p

Seeley M, et al (2015) High resolution profiles of elements in Atlantic tarpon (Megalops atlanticus) scales obtained via cross-sectioning and laser ablation ICP-MS: a review and novel approach for scale analyses. Environ Biol Fish. doi: 10.1007/s10641-015-0443-z

Schlaifer A, Breder CM (1940) Social and respiratory behavior of small tarpon. Zoology 25:493-512

Shaklee JB, Tamaru CS (1981) Biochemical and morphological evolution of Hawaiian bonefishes (Albula). System Biol 30: 125-146

Shenker JM, Cowie-Mojica E, Crabtree RE, Patterson HM, Stevens C, Yakubik K (2002) Recruitment of tarpon (Megalops atlanticus) leptocephali into the Indian river lagoon, Florida. Contr Mar Sci 35:55-69

Snodgrass D, Crabtree RE, Serafy JE (2010) Abundance growth, and diet of young-of-the-year bonefish (Albula spp.) off the Florida keys, U.S.A. Bull Mar Sci 82:185-193

Steinberg, M (2015) A Nationwide assessment of threats to bonefish, tarpon, and permit stocks in Belize. Environ Biol Fish. doi:10.1007/s10641-015-0429-x

Turner SJ, Thrush SF, Hewitt JE, Cummings VJ, Funnell G (1999) Fishing impacts and the degradation or loss of habitat structure. Fish Manag Ecol 6:401-420

Twomey E, Byrne P (1985) A new record for the tarpon, Megalops atlanticus valenciennes (osteichthyes-elopiformes-elopidae), in the eastern north Atlantic. J Fish Biol 26:359-362

Wade RA (1962) The biology of the tarpon, Megalops atlanticus, and the ox-eye, Megalops cyprinoides, with emphasis on larval development. Bull Mar Sci 12:545-599

Wallace EM, Tringali MD (2010) Identification of a novel member in the family albulidae (bonefishes). J Fish Biol 76:19721983

Wallace EM (2015) A preliminary assessment of species distributions, fishery composition, and population structure in the Indo-Pacific bonefishes. Env Biol Fish. doi:10.1007/s10641015-0416-2

Warmke GL, Erdman DS (1963) Records of marine mollusks eaten by bonefish in Puerto Rican waters. Nautilus 76:115121

Whitehead PJP, Vergara R (1978) Megalopidae. In W. Fischer (ed.) FAO species identification sheets for fishery purposes. Western Central Atlantic (Fishing Area 31). Vol. 3. FAO, Rome.

Zale AV, Merrifield SG (1989) Species Profiles: Life Histories and Environmental Requirements of Coastal Fishes and Invertebrates (South Florida) - Ladyfish and Tarpon. U.S. Fish and Wildlife Servive Biological Report 82(11.104). $17 \mathrm{pp}$.

Zerbi A, Aliaume C, Joyeux JC (2001) Growth of juvenile tarpon in Puerto Rican estuaries. ICES, J Mar Sci 58:87-95 